\title{
Calpain II in rat peripheral nerve
}

\author{
Marina Mata, Nancy Kupina and David J. Fink \\ Department of Neurology, University of Michigan and GRECC Neurology Reserach Laboratory, VAMC, Ann Arbor, MI 48105 (U.S.A.)
}

(Accepted 13 August 1991)

Key words: Calpain; Peripheral nerve; Schwann cell; Immunocytochemistry; Rat

\begin{abstract}
We used a polyclonal antiserum directed against calpain II to study the distribution of that enzyme in rat sciatic nerve. Western blot of nerve homogenate showed that the antibody reacted with a single protein band of $80 \mathrm{kDa}$, corresponding to the catalytic subunit of calpain II. By light microscopy, immunoreactivity appeared predominantly in Schwann cell cytoplasm. By electron microscopy, calpain II was especially dense along the plasmalemma of Schwann cells, and was also seen in axoplasm.
\end{abstract}

Calpains (calcium activated neutral protease, EC 3.4.22.17) are a widely distributed family of cysteine proteases ${ }^{9}$. Calpain I is activated by $\mu \mathrm{M} \mathrm{Ca}^{2+}$, while calpain II requires $\mathrm{mM} \mathrm{Ca}^{2+}$ for activation ${ }^{17,18,30}$. Along with their endogenous inhibitor calpastatin ${ }^{19}$, both enzymes are found in most tissues including the nervous system ${ }^{6}$, 32. Each calpain consists of a catalytic subunit $\left(M_{\mathrm{r}}=80\right.$ $\mathrm{kDa}$ ) which is distinct for each calpain, and a smaller $\left(M_{\mathrm{r}}=30 \mathrm{kDa}\right)$ subunit which is common to both calpains ${ }^{17}$. The different calpain subunits are the products of distinct genes in $\operatorname{man}^{20}$. Many proteins have been identified as potential calpain substrates by in vitro assays ${ }^{9}$.

Both calpain $\mathrm{I}^{10,13}$ and calpain $\mathrm{II}^{11,12,26}$ have been isolated from peripheral nerve. In vitro, each of these enzymes is capable of degrading neurofilaments ${ }^{10-13,26}$ in addition to tubulin and microtubule associated proteins $\mathrm{I}$ and $\mathrm{II}^{5}$. Calpain II in the central nervous system coisolates with myelin, and is capable of degrading several myelin proteins in vitro ${ }^{4}$. The natural substrates of calpain in vivo must be determined by the spatial distribution of the enzyme and its function, dependent on the local control of $\mathrm{Ca}^{2+}$ concentration.

Previous immunocytochemical studies of calpain distribution in the nervous system have focused on the brain. Calpain $I$ is found in neuronal perikarya in many brain regions ${ }^{7,8,21,22,29}$ and has been described in glia by some $^{21,22}$, but not by other ${ }^{7,8}$ investigators. Similarly, calpain II has been described as predominantly in glia in brain by some ${ }^{8}$, but not by other ${ }^{7}$ investigators. In the only previous electron microscopic immunocytochemical study of peripheral nerve, an antibody directed against calpains showed immunoreactivity in monkey nerve extracellularly along collagen fibrils and basal lamina, along the axolemma, and on neurofilaments intracellularly ${ }^{1}$. In order to better understand the potential role of calpain II in normal nerve function, we used a polyclonal antibody specific for calpain $\mathrm{II}^{24}$ for light and electron microscopic immunocytochemistry of rat sciatic nerve.

The polyclonal antibody generated against rat platelet calpain II (a generous gift of J. Elce) has been previously characterized $^{24}$. It has a much higher affinity for rat calpain II than it does for rat calpain I (Fig. 2 in ref. 24).

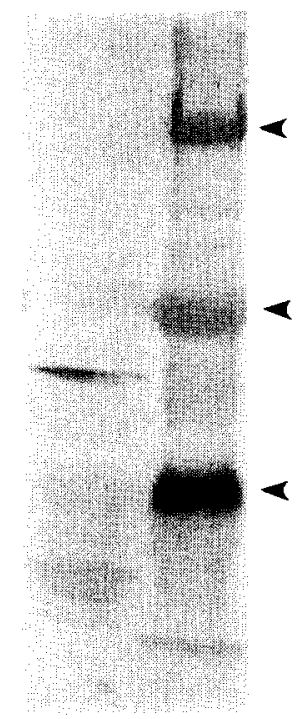

Fig. 1. Western blot of homogenate of sciatic nerve using the anticalpain II antibody. The blot was exposed to the primary antibody $(1: 100)$ overnight, and the secondary antibody $(1: 200)$ for $1 \mathrm{~h}$. A single band of $M_{\mathrm{r}}=80 \mathrm{kDa}$ is seen (left lane). Molecular weight standards (right lane): 200, 98, $67 \mathrm{kDa}$ (arrows). 
In order to determine the antibody's specificity against proteins isolated from nerve, we performed a Western blot $^{14,31}$ of protein from rat sciatic nerve homogenized in $5 \mathrm{mM} \mathrm{NaCl}, 50 \mathrm{mM}$ Tris, $\mathrm{pH}$ 7.4. The antibody recognized a single band of $M_{\mathrm{r}}=80 \mathrm{kDa}$ (Fig. 1), corresponding to the catalytic subunit of calpain II, and indicating that the antibody does not cross-react with other proteins (of different molecular weight) in peripheral nerve.

For light microscopic immunocytochemistry, the rats were perfused with $4 \%$ paraformaldehyde for $1 \mathrm{~h}$. The nerves were removed, cryoprotected with $2.3 \mathrm{M}$ sucrose overnight, and $1 \mu \mathrm{m}$ sections cut at $-80^{\circ} \mathrm{C}$ were placed on gelatin-coated slides. The slides were blocked with $1 \%$ ovalbumin in $20 \mathrm{mM}$ glycine and $20 \mathrm{mM}$ Tris-saline (pH 7.6) for $15 \mathrm{~min}$, exposed to the primary antibody (1:5 to

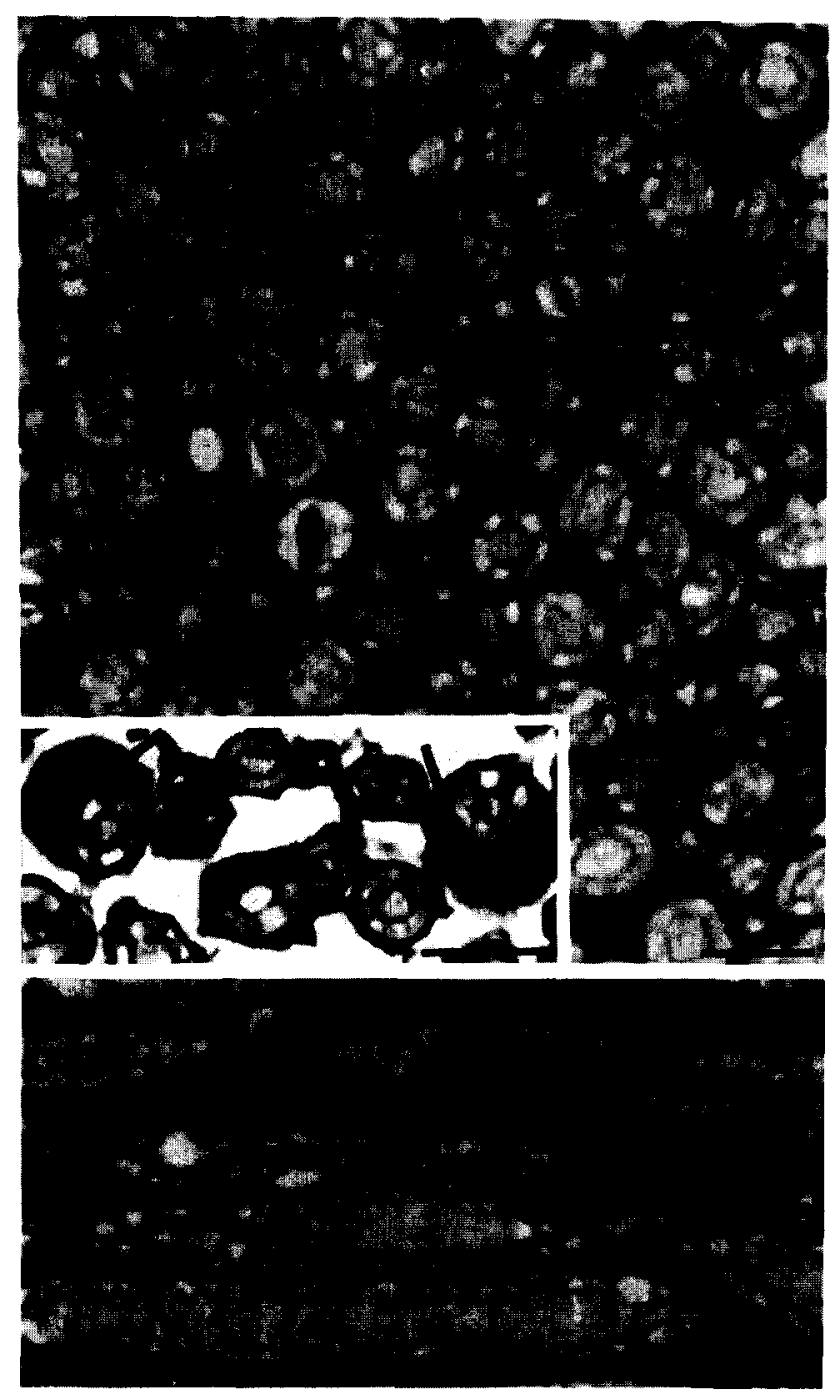

Fig. 2. Light microscopic immunocytochemistry of sciatic nerve, stained with streptavidin-biotin-HRP. Immunoreactivity is seen in Schwann cell cytoplasm (arrows). A: cross section. Insert shows individual fibers separated from the endoneurial matrix. B: longitudinal section. Bars $=10 \mu \mathrm{m}$.
$1: 100)$ overnight, followed by goat anti-rabbit antibody conjugated to biotin for $1 \mathrm{~h}$, streptavidin peroxidase (1:100) for $1 \mathrm{~h}$, and developed with diaminobenzidine tetrahydrochloride for $15 \mathrm{~min}$.

For electron microscopy, ultrathin sections were cut at $-120^{\circ} \mathrm{C}$, and the sections on grids exposed to the antiserum (1:5 to $1: 20$ dilutions) for $2 \mathrm{~h}$, followed by goat anti-rabbit IgG bound to $15 \mathrm{~nm}$ colloidal gold as described $^{15}$. The grids were stained for 20 min with uranyl acetate and examined in a JEOL 100 S electron microscope. As a control for the immunocytochemical reactions, we performed the same reaction but deleted the primary antibody.

With both the light and the EM immunocytochemistry, the amount of immunoreactivity decreased with progressive dilution of the antibody, but the distribution of immunoreactivity was unchanged.

This antigen-antibody reaction was very sensitive to aldehyde fixation. Post-embedding immunocytochemistry on tissue embedded in LR White, or on etched, osmicated polybed or LR White grids produced no signal. Because of the low fixative content required to preserve antigenicity, the morphology in the cryo-ultrathin section was not optimal, and while the antigen could be localized at the cellular level, fine detail, particularly of the basal lamina and intracellular compartments, was not preserved.

By light microscopy it was apparent that immunoreactivity with this antibody was confined predominantly to Schwann cells (Fig. 2). Little immunoreactivity was detected within axons and there was no immunoreactivity in the myelin. The control showed no reaction product (Fig. 3).

By electron microscopy, gold grains indicating immunoreactivity were found diffusely within the cytoplasm of Schwann cells (Fig. 4), and were especially prominent along the plasmalemma of those cells (Fig. 4C). In many instances the plasmalemmal immunoreactivity was so

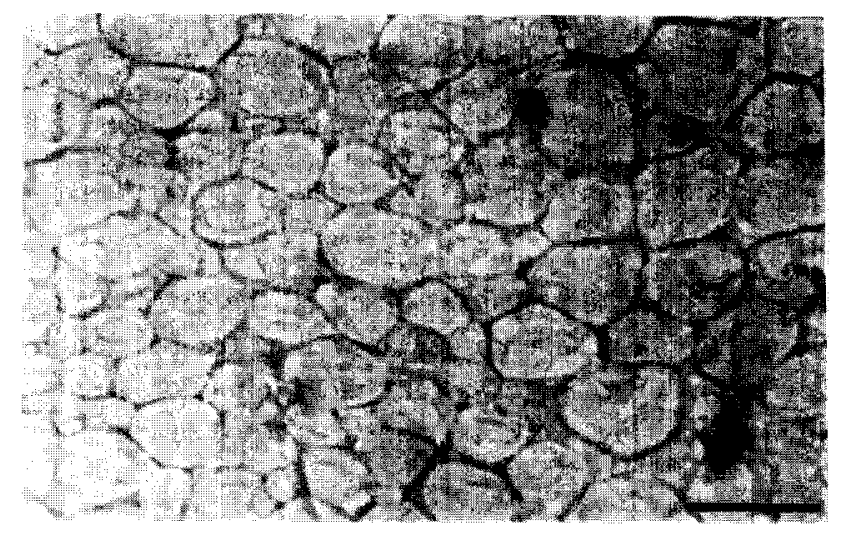

Fig. 3. Control, with deletion of primary antibody. Bar $=10 \mu \mathrm{m}$. 


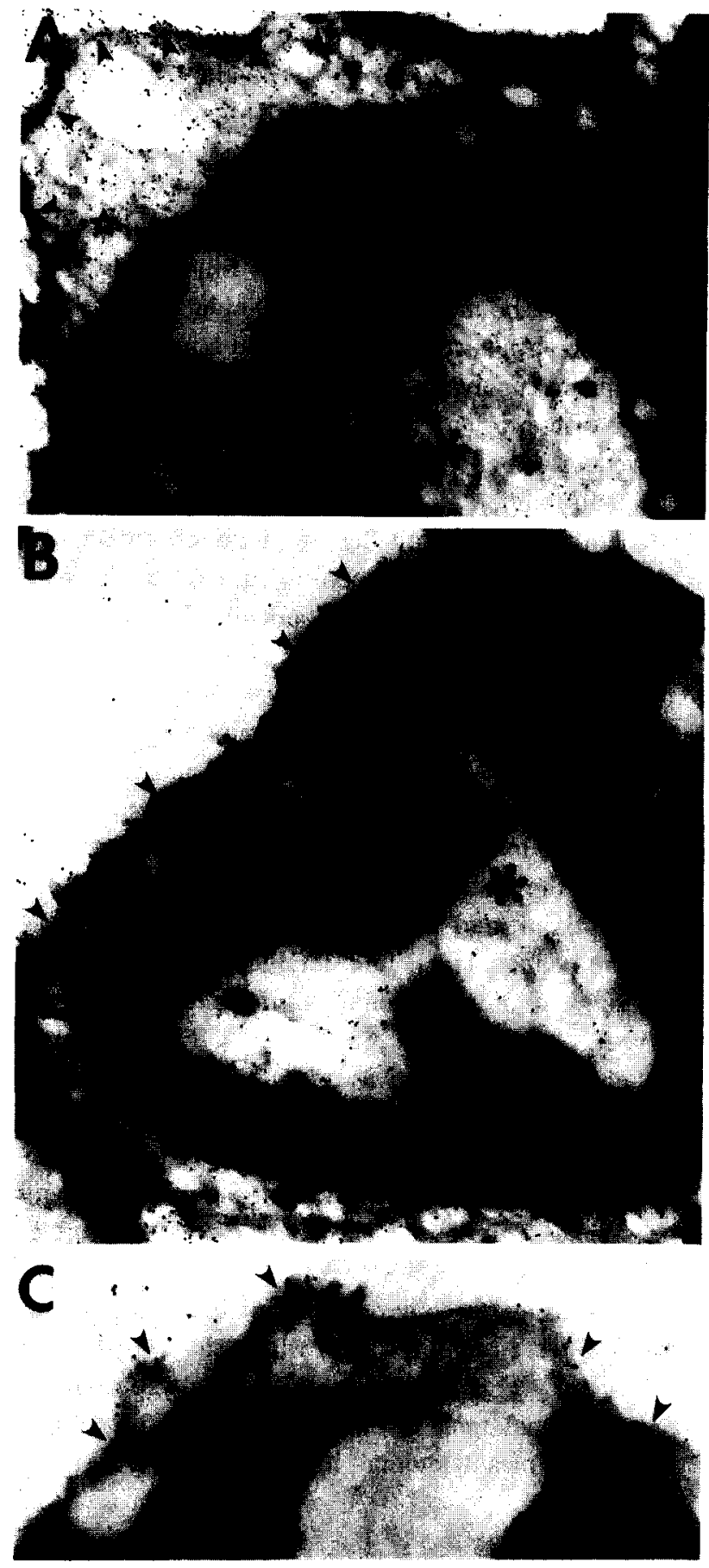

Fig. 4. Electron microscopic immunocytochemistry, with colloidal gold, of cryo-ultrathin section of nerve, shows immunoreactivity along the Schwann cell membrane (arrowheads), in Schwann cell cytoplasm (stars), and in axoplasm (asterisks). Original magnifications: $\mathrm{A}, \times 16,800 ; \mathrm{B}, \times 22,400 ; \mathrm{C}, \times 25,500$.

dense that the gold particles obscured the extracellular face of the plasma membrane as well as the basal lamina (Fig. 4A, B). There was also clear immunoreactivity within axons (Fig. 4), but it appeared to be less intense than the immunoreactivity within Schwann cells. Although occasional gold particles were seen in myelin, there was no consistent immunoreactivity above background in the myelin. Considered with the absence of myelin immunoreactivity by light microscopy, we feel it is most likely that calpain II is not found in significant amounts in compact myelin.

These results are important in considering the possible role of calpain II in the peripheral nerve. Calpain II has been implicated in the degradation of neurofilaments that characterizes Wallerian degeneration triggered by the influx of $\mathrm{Ca}^{2+}$ into axons, distal to the site of injury $^{27,32}$. The intra-axonal localization of calpain II is consistent with this function. Similarly, calpain II can degrade myelin basic protein and myelin proteolipid protein in vitro ${ }^{4}$, and is capable of converting myelin associated glycoprotein to a smaller derivative ${ }^{25}$. The Schwann cell localization suggests that this mechanism could potentially occur in vivo if local $\mathrm{Ca}^{2+}$ concentration were elevated, although the absence of myelin immunoreactivity implies that it is not the mechanism for turnover of these proteins within myelin.

The prominent association of calpain II with Schwann cell membranes was of particular interest. In other systems, calpains associate with membrane phospholipids ${ }^{16}$ and with integral membrane proteins ${ }^{23}$, and it has been suggested that calpain may be activated at the membrane and might mediate membrane lipid and protein interactions?.

The results of the current study differ from the results of Badalamente et al. ${ }^{1}$, who reported a predominantly extracellular localization of immunoreactivity in monkey peripheral nerve, using an anti-calpain antibody of undefined isoenzyme specificity. However, our results are in agreement with the results reported by Hamakubo et al. ${ }^{8}$, who found a glial localization of calpain II in brain, and detected immonostaining of axons as well, and are supported by the recent report of calpain II in Schwann cells in vitro ${ }^{3}$.

Recent experimental evidence suggests that calpain activity might be important in regulating neurite outgrowth in vitro ${ }^{28}$ and in vivo ${ }^{2}$. Further studies of calpain distribution in response to nerve injury are currently underway in our laboratory.

We thank Dr. John Elce for the kind gift of the anti-calpain antibody. This work was supported by grants from the NINDS (NS27771, DJF) and by VA Merit Review Grants (DJF and MM). These results were presented in abstract form at the annual meeting of the Society for Neuroscience at New Orleans, LA, in November 1991 . 
1 Badalamente, M.A., Hurst, L.C. and Stracher, A., Localization and inhibition of calcium-activated neutral protease (CANP) in primate skeletal muscle and peripheral nerve, Exp. Neurol., 98 (1987) 357-369.

2 Badalamente, M.A., Hurst, L.C. and Stracher, A., Neuromuscular recovery using calcium protease inhibition after median nerve repair in primates, Proc. Natl. Acad. Sci. U.S.A., 86 (1989) 5983-5987.

3 Banik, N., DeVries, G., Neuberger, T., Russell, T., Chakrabarti, A. and Hogan, E., Calcium-activated neutral proteinase (CANP) in Schwann cells, Trans. Am. Soc. Neurochem., 21 (1990) 237 (Abstract).

4 Banik, N.L., McAlhaney, W. and Hogan, E.L., Calcium-stimulated proteolysis in myelin: evidence for a $\mathrm{Ca}^{2+}$-activated neutral proteinase associated with purified myelin of rat CNS, $J$. Neurochem., 45 (1985) 581-588.

5 Billiger, M., Wallin, M. and Karlsson, J-O., Proteolysis of tubulin and microtubule-associated proteins 1 and 2 by calpain $I$ and II. Difference in sensitivity of assembled and disassembled microtubules, Cell Calcium, 9 (1988) 33-44.

6 Blomgren, K., Nillson, E. and Karlsson, J-O., Calpain and calpastatin levels in different organs of the rabbit, Comp. Biochem. Physiol., 93B (1989) 403-407.

7 Fukuda, T., Adachi, E., Kawahima, S., Yoshiya, I. and Hashimoto, P., Immunohistochemical distribution of calcium-activated neutral proteinases and endogenous CANP inhibitor in the rabbit hippocampus, J. Comp. Neurol., 302 (1990) 100-109.

8 Hamakubo, T., Kannagi, R., Murachi, T. and Matus, A., Distribution of calpains I and II in rat brain, J. Neurosci., 6 (1986) 3103-3111.

9 Johnson, P., Calpains (intracellular calcium-activated cysteine proteinases): structure-activity relationships and involvement in normal and abnormal cellular metabolism, Int. J. Biochem., 22 (1990) 811-822.

10 Kamakura, K., Ishiura, S. and Sugita, H., $\mu$-Type calcium activated neutral protease in the rat peripheral nerve, $J$. Neurosci. Res., 15 (1986) 167-173.

11 Kamakura, K., Ishiura, S., Sugita, H. and Toyokura, Y., Identification of $\mathrm{Ca}^{2+}$-activated neutral protease (CANP) in the rat peripheral nerve, Biomed. Res., 3 (1982) 91-94.

12 Kamakura, K., Ishiura, S., Sugita, H. and Toyokura, Y., Identification of $\mathrm{Ca}^{2+}$-activated neutral protease in the peripheral nerve and its effects on neurofilament degeneration, $J$. Neurochem., 40 (1983) 908-913.

13 Kamakura, K., Ishiura, S., Suzuki, K., Sugita, H. and Toyokura, Y., Calcium-activated neutral protease in the peripheral nerve, which requires $\mu \mathrm{M}$ order $\mathrm{Ca}^{2+}$, and its effect on the neurofilament triplet, J. Neurosci. Res., 13 (1985) 301-403.

14 Laemmli, V.K., Cleavage of structural proteins during the assembly of the head of bacteriophage T4, Nature, 227 (1970) 680-685.

15 Mata, M., Alessi, D. and Fink, D.J., S100 is preferentially distributed in myelin-forming Schwann cells, J. Neurocytol., 19 (1990) 432-442.
16 Mellgren, R.L., Calcium-dependent proteases: an enzyme system active at cellular membranes, FASEB J., 1 (1987) 110-115.

17 Melloni, E. and Pontremoli, S., The calpains, TINS, 12 (1989) 438-444.

18 Murachi, T., Calpain and calpastatin, Trends Biochem. Sci., 8 (1983) $167-169$.

19 Nishiura, I., Tanaka, K. and Murachi, T., A high molecular weight inhibitor of $\mathrm{Ca}^{2+}$-dependent neutral protease in rat brain, Experientia, (1979) 1006-1007.

20 Ohno, S., Minoshima, S., Kudoh, J., Fukuyama, R., Shimizu, Y., Ohmi-Imajoh, S., Shimizu, N. and Suzuki, K., Four genes for the calpain family locate on four distinct human chromosomes, Cytogenet. Cell Genet., 53 (1990) 225-229.

21 Perlmutter, L.S., Gall, C., Baudry, M. and Lynch, G., Distribution of calcium-activated protease calpain in the rat brain, $J$. Comp. Neurol., 296 (1990) 269-276.

22 Perlmutter, L.S., Siman, R., Gall, C., Seubert, P., Baudry, M. and Lynch, G., The ultrastructural localization of calcium-activated protease 'Calpain' in rat brain, Synapse, 2 (1988) 79-88.

23 Sakai, K., Hayashi, M., Kawashima, S. and Akanuma, H., Calcium-induced localization of calcium-activated neutral proteinase on plasma membranes, Biochim. Biophys. Acta, 985 (1989) 51-54.

24 Samis, J.A., Zboril, G. and Elce, J.S., Calpain I remains intact and intracellular during platelet activation, Biochem. J., 246 (1989) 481-488.

25 Sato, S., Yanagisawa, K. and Miyatake, T., Conversion of myelin-associated glycoprotein (mag) to a smaller derivative by calcium activated neutral protease (canp)-like enzyme in myelin and inhibition by E-64 analogue, Neurochem. Res., 9 (1984) 629-635.

26 Schlaepfer, W.W. and Micko, S., Chemical and structural changes of neurofilaments in transected rat sciatic nerve, $J$. Cell Biol., 78 (1978) 369-378.

27 Schlaepfer, W.W. and Micko, S., Calcium-dependent alterations of neurofilament proteins of rat peripheral nerve, J. Neurochem., 32 (1979) 244-249.

28 Shea, T.B., Beermann, M.L. and Nixon, R.A., Multiple proteases regulate neurite outgrowth in NB2a/dl neuroblastoma cells, J. Neurochem., 56 (1991) 842-851.

29 Siman, R., Gall, C., Perlmutter, L.S., Christian, C., Baudry, M. and Lynch, G., Distribution of calpain I, an enzyme associated with degenerative activity, in rat brain, Brain Research, 347 (1985) 399-403.

30 Suzuki, K., Tsuji, S., Kubota, S., Kimura, Y. and Imahori, K., Limited autolysis of $\mathrm{Ca}^{2+}$ activated protease (CANP) changes its sensitivity to $\mathrm{Ca}^{2+}$ ions, J. Biochem., 90 (1981) 275-278.

31 Towbin, H., Staehelin, T. and Gordon, J., Electrophoretic transfer of proteins from polyacrylamide gels to nitrocellulose sheets: procedure and some applications, Proc. Natl. Acad. Sci. U.S.A., 76 (1979) 4350-4354.

32 Zimmerman, U.-J.P. and Schlaepfer, W.W., Calcium-activated neutral protease (canp) in brain and other tissues, Prog. Neurobiol., 23 (1984) 63-78. 